\title{
ИННОВАЦИОННАЯ ТЕХНОЛОГИЯ ЛИПОСОМИРОВАНИЯ В ПРОИЗВОДСТВЕ БАД ПОЛИФУНКЦИОНАЛЬНОГО ДЕЙСТВИЯ
}

\author{
Б.Тохириён, Е. В. Вялых, А.Н. Австриевских, В.М. Позняковский
}

\begin{abstract}
Разработана инновационная технология нового вида специализированного продукта биологически активной добавки (БАД). Технология производства обеспечивает высокую сохранность биологически активных компонентов за счет липосомирования. Липосомирования дает возможность одновременной доставки в организм активных веществ, имеющих различные пути проникновения и всасывания, но при этом общую точку приложения биологических эфрфектов. Указанную фрункциональную направленность дополняет наличие в составе БАД других биологически активных веществ, усиливающих естественную защиту организма в рассматриваемых условиях, предупреждая алиментарные хронические заболевания. Проведение санитарногигиенических и санитарно-токсикологических исследований позволило установить сроки и режимы реализации - 2 года, в сухом месте при температуре не выше $22 \pm 3^{\circ} \mathrm{C}$. Также показано гигиеническое благополучие разработанного продукта. Употребление нового специализированного продукта форме БАД по 1-2 капсулы в день, гарантирует потребление витаминов в соответствии с заданными функциональными свойствами. Необходимо отметить, что специализированный продукт прошел испытания в Роспотребнадзора и головном испытательном иентре Института питания РАН, получено свидетельство о государственной регистрации, что послужила основанием для внесения биологически активной добавки (БАД) в фредеральный Реестр.

Ключевые слова: Биологически активный комплекс - БАД, производство, инновационная технология, качество, безопасность, эфффективность, фрункциональная направленность.
\end{abstract}

\section{ВВЕДЕНИЕ}

Разработка инновационных технологий в производстве специализированных продуктов, в том числе биологически активных добавок к пище «БАД» играет важное значение в формировании качественных характеристик разрабатываемой продукции [1,3-5].

Особую актуальность этот вектор исследований приобретает для обеспечения стабильности биологически активных компонентов рецептуры, определяющих функциональные свойства [2,6-8].

Цель исследования. Заключается в разработке инновационной технологии производства и определении регламентируемых показателей качества нового специализированного продукта в форме БАД.

\section{МАТЕРИАЛЫ И МЕТОДЫ}

В качестве материалов использованы растительное сырье и препараты биологи- чески активных веществ. Применяли общедоступные и специальные методы исследования качества, безопасности, эффрективности и функциональной направленности нового продукта.

\section{РЕЗУЛЬТАТЫ ИССЛЕДОВАНИЙ}

Научно обоснованная рецептурная формула нового вида БАД, мг в одной капсуле массой 1620 мг: рыбий жир (эйкозапентаеновая и докозагексаеновая кислоты) - 500; льняное масло (альфра-линоленовая кислота) - 455; липосомы с дигидрокверцетином (дигидрокверцетин фосфолипиды) - 150; липоевая кислота - 9,0; токоферола ацетат (витамин Е) -3,06; Селексен (селен)-0,043. Вспомогательные вещества: мальтодекстрин-46,3; диоксид кремния-36; антиоксидант GRINDOX 539-0,6; капсула желатиновая (желатин, глицерин) -420.

Технология производства включает стадии, представленные на рисунке 1. 


\section{ИННОВАЦИОННАЯ ТЕХНОЛОГИЯ ЛИПОСОМИРОВАНИЯ В ПРОИЗВОДСТВЕ БАД ПОЛИФУНКЦИОНАЛЬНОГО ДЕЙСТВИЯ}

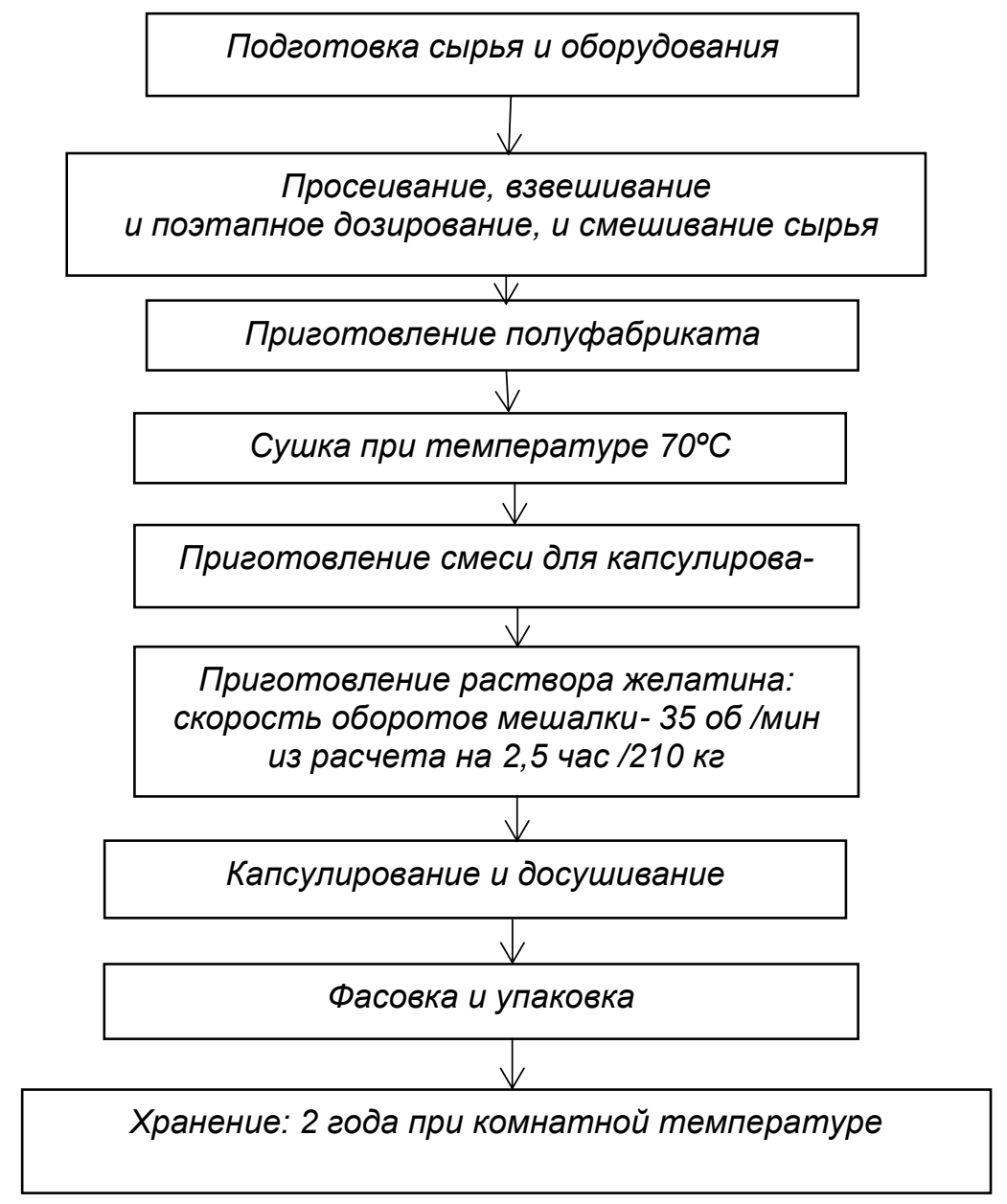

Рисунок 1 - Технологическая схема производства БАД

Подготовка сырья. Сырье поступает со склада с сопроводительными документами, подтверждающими его соответствия техническим регламентам ТР ТС 021/2011 «О безопасности пищевой продукции», ТР ТС 029/2012 «Требования безопасности пищевых добавок, ароматизаторов и технологических вспомогательных средств» и сопровождаться документами, подтверждающими качество и безопасность. Допускается использовать аналогичное сырье отечественного и зарубежного производства с аналогичными характеристиками. Липоевую кислоту, дигидрокверцетин и мальтодекстрин предварительно просеивают через вибросито SGS-30.

Приготовление полуфабриката - сухой липосомированной субстанции с дигидрокверцетином. Осуществляет раздельное дозирование компонентов в следующей последовательности: лецитин; мальтодекстрин; вода, дигидрокверцетин.

Лецитин смешивают с мальтодекстрином в V-образном смесителе C-300 (часть 1). Ди- гидрокверцетин растворяют в воде при нагревании до $60{ }^{\circ} \mathrm{C}$ в гомогенизаторе (часть 2). Част 1 добавляют порциями к части 2, смешивают в течение часа и гомогенизируют 4 мин. до однородной массы. Проверяют соответствие наименования, количества и серии сырья технологической карте. Не должно быть комков и посторонних включений.

Сушка. Смесь для высушивания подают в распылительную сушилку PC-10 и сушит при температуре $70^{\circ} \mathrm{C}$. Комки и посторонние включения должны отсутствовать;

Приготовление смеси для капсулирования. Порядок дозирования и смешения представлен в таблице 1.

Не допускается хранение смеси для капсулирования более 3 суток без использования упаковки, исключающей доступ кислорода воздуха и света.

По окончании процесса проверяется соответствие наименования, количества и серии сырья технологической карте. Не должно быть комков и посторонних включений. 
Таблица 1- Порядок дозирование и смешения компонентов БАД

\begin{tabular}{|c|c|c|c|}
\hline Наименование & \multicolumn{2}{|c|}{ Порядок дозирования } & Примечание \\
\hline \multirow[t]{8}{*}{ Дозирование } & \multirow{8}{*}{$\begin{array}{l}\text { Компоненты } \\
\text { дозируются } \\
\text { в указанном } \\
\text { порядке } \\
\text { учитывая } \\
\text { примеча- } \\
\text { ние. }\end{array}$} & Рыбий жир (18/12\%) & \\
\hline & & Льняное масло & \\
\hline & & Липоевая кислота & $\begin{array}{l}\text { Вностить в масла при нагревании } \\
50^{\circ} \mathrm{C} \text { и постоянном перемешива- } \\
\text { нии }\end{array}$ \\
\hline & & Диоксид кремния & $\begin{array}{l}\text { Перемешать и гомогенизировать } \\
\text { 5-10минут }\end{array}$ \\
\hline & & Липосомы с ДКВ 5\% & $\begin{array}{l}\text { Перемешать и гомогенизировать } \\
\text { 5-10минут }\end{array}$ \\
\hline & & Селексен (23\% селена) & Растворить при $70^{\circ} \mathrm{C}$ в части \\
\hline & & $\begin{array}{l}\text { Антиоксидант GRINDOX } \\
109\end{array}$ & $\begin{array}{l}\text { (1,5КГ) Льняного масла Или смеси } \\
\text { льняного масла и рыбьего жира }\end{array}$ \\
\hline & & Токоферола ацетат & $\begin{array}{l}\text { Добавить в остывшую смесь (при } \\
\text { температуре не выше } 55^{\circ} \text { ) }\end{array}$ \\
\hline
\end{tabular}

Приготовление раствора желатина. Задаются параметры в программном обеспечении смесителя Melter MGP: температура воды в рубашке $-85^{\circ} \mathrm{C}$, количество воды очищенной - согласно загрузочной карте, скорость оборотов мешалки - 35 об/мин. Взвешенные компоненты загружают в следующей последовательности: вода очищенная, глицерин, желатин. В последнюю очередь добавляют вспомогательные компоненты (консерванты и пигменты) согласно загрузочной карте.

Раствор приготавливают из расчета на 210 кг готового раствора желатина - 2.5 часа. После окончания процесса готовый раствор выгружают через сито 0,2 мм в емкости для хранения раствора желатина. После выгрузки отстаивают в емкостях для хранения раствора желатина 4 часа при постоянной температуре $60^{\circ} \mathrm{C}$. После отстаивания раствор желатина подают на участок изготовления капсул. Срок хранения готового раствора не более 24 чаCOB;

Капсулирование и досушивание. Мягкие желатиновые капсулы производит из готового раствора желатина и смеси для капсулирования на капсульной машине SGM 1010. После окончания процесса изготовления, капсулы досушивают в сушильных тоннелях 40-50 часов до прекращения падения массы капсулы;

Оценка внешнего вида полупродукта. Капсулы должны соответствовать внешнему виду требованиям технической документации. Производит взвешивания капсул и упаковку. На этикетке указывают наименование полупродукта, количество, номер партии, дату изготовления, подпись оператора и передают на 54 стадию «Фасовка и упаковка».

Конкурентными преимуществами разработанной технологии являются:

- активные нового вещества комплекса заключены в мягкую желатиновую капсулу. Это обеспечивает повышение ряда потребительских качества продукта по сравнению с твердой формой: препарат герметичен, строго дозирован, не имеет вкуса и запаха, а также имеет увеличенный срок годности по сравнению с аналогичными препаратами в твердой капсуле.

- инновационная технология доставки активных веществ- липосомирование. Технология липосомирования дает возможность одновременной доставки в организм активных веществ, имеющих различные пути проникновения и всасывания, но при этом общую точку приложения биологических эффектов. Омега3 витамин E - жирорастворимые компоненты, а дигидрокверцетин - водорастворимый, однако инновационная форма доставки их в организм дает возможность одновременного попадания, синхронного действия и обеспечивает тройную защиту сердца и сосудов от атеросклероза.

Продукт прошел испытания в Роспотребнадзоре и головном испытательном центре Института питания РАН, получено свидетельство о государственной регистрации, что послужила основанием для внесения БАД в фредеральный Реестр. Согласно проведенным исследованиям компоненты комплекса незаменимые омега-3 и омега -6 жирные кислоты растительного (льняное масло) и животного (рыбий жир) происхождения -препятствуют 


\section{ИННОВАЦИОННАЯ ТЕХНОЛОГИЯ ЛИПОСОМИРОВАНИЯ В ПРОИЗВОДСТВЕ БАД ПОЛИФУНКЦИОНАЛЬНОГО ДЕЙСТВИЯ}

формированию воспалительных реакций, принимают формированию воспалительных реакций, принимает активное участие в регуляции тонуса сосудов кровеносной системы, стимулируют активность имунной системы, снижают уровень холестерина, обеспечивая профилактику атеросклероза уменьшают степень проявления болевого синдрома. Сочетание ПНЖК с витаминами Е нормализует процессы свертывания крови и тромбообразования, артериальное давление. Кроме того, витамин Е препятствует окислению омега -3 и омега - 6 кислот, что благоприятно сказывается на сохранении всех ценных свойств и активности компонентов комплекса.

Продукт позиционируется в качестве биологически активного комплекса для профилактики распространённых заболеваний и защиты от вредного воздействия окружающей среды.

Прием одной капсулы (рекомендуемая суточная доза) обеспечивает требуемый уровень потребления эссенциальных нутриентов в соответствии с направлением использования специализированного пищевого продукта (табл. 2).

Таблица 2- Содержание эссенциальных нутриентов специализированного продукта

\begin{tabular}{|l|c|c|}
\hline \multicolumn{1}{|c|}{ Наименование } & мг & \% от РСП \\
\hline Эйкозапентаеновая кислота & 90 & 35 \\
\hline Докозагексаеновая кислота & 60 & 35 \\
\hline Альра-линоленовая кислота & 200 & 35 \\
\hline Липоевая кислота & 9 & 30 \\
\hline Дигидрокверцитин & 7,5 & 30 \\
\hline Витамин Е & 3 & 30 \\
\hline Селен & 0,01 & 15 \\
\hline
\end{tabular}

Специализированный продукт в форме БАД производится на предприятиях компании «Арт -Лайфр» (г. Томск), сертифицированных в рамках требований международных стандартов серии ИСО 9001, 22000 и правил GMP, что обеспечивает стабильность качества и конкурентоспособность.

\section{СПИСОК ЛИТЕРАТУРЫ}

1. Тохириён, Б. Регулируемые технологические параметры производства БАД «Софиа» - как фрактор формирования качества инновационного продукта / Б. Тохириён, А. Н. Австриевских, В.М. Позняковский // Новые технологии.- 2018. - № 1. C. 88-93.

2. Штерман, С.В. Функциональный пищевой продукт для поддержания здоровья суставов и связок "ДЖОЙНТ ПЕРФЕКТ" // С.В. Штерман, М.Ю. Сидоренко, В.С. Штерман, Ю.И. Сидоренко // Пищевая промышленность. 2018. № 4. С. 66-68.

3. Лобач, Е.Ю. Инновационная технология производства и оценка потребительских свойств фитокомплекса "Ивлаксин" / Е.Ю. Лобач, А.Н. Австриевских, В.М. Позняковский // Инновации и продовольственная безопасность. 2018. № 2 (20). С. 7 13.

4. Подзорова, Г.А., Регламентируемые технологические параметры производства в формировании потребительских свойств БАД "Мемори Райс" / Г.А. Подзорова, А.Н. Австриевских, В.М. Позняковский // Современная наука и инновации. - 2018. - № 1 (21).- с. 73-78.
5. Тохириён, Б. Рецептурный состав и технология производства нового вида инновационной формы БАД / Б.Тохириён, Д.А. Челнакова, В.П. Ердакова , В.М. Позняковский // Технология и товароведение инновационных пищевых продуктов. 2017. - № 1 (42). - С. 38-43.

6. Гончаренко, М.С. Исследование влияния продукта питания с добавленной ценностью на функциональное состояние организма / М.С. Гончаренко, А.В. Мельникова, Е.Н. Лебедь, С.Н. Петрова, Л.Г. Елисеева. // Актуальные научные исследования в современном мире.- 2018. -№ 2-3 (34). С. 43-49.. С. 73-78.

7. Карамнова Н.С. Использование функциональных продуктов питания в профилактике хронических неинфекционных заболеваний / Н.С. Карамнова // CardioСоматика. - 2017. - Т. 8. - № 1. - С. 39.

8. Юлдашева, Ш.Ж Свойства продуктов функционального питания / Ш.Ж. Юлдашева, Н.И. Алиева, М.Б. Камалова // Вопросы науки и образования.- 2018. - № 2 (14). - С. 30-31.

9. Пат. 2621989 РФ, МПК А 23L 33/00. Способ производства пищевого функционального продукта / Лисовой В.В., Викторова Е.П., Корнен Н.Н., Першакова Т.В., Федосеева О.В., Великанова Е.В.№2621989; заявл. 17.08.2016; опубл. 08.06.2017.

10.Луницын, В.Г. Новые продукты функционального питания на основе продукции мараловодства / В.Г. Луницын , А.А. Неприятель // Сибирский вестник сельскохозяйственной науки. - 2017. - Т. 47. - № 4 (257).- C. 82-87.

11.Интернет магазин товаров для здоровья и красоты [электронный ресурс]. - Режим доступа: http://www.domzdorovye.ru/site.xp/049049051050124 054049048056.html. 
Тохириён Боисджони, к.т.н., докторант кафредры товароведения и экспертизы ФГБОУ ВО «Уральский государственный экономический университет», 620019, Российская Федерация, 2. Екатеринбург, ул. 8 мapma, 62, e-mail: tohiriyoni@gmail.com.

Вялых Елена Викторовна, аспирант базовой кафредры «Пищевая индустрия и функциональное питание» ФГБОУ ВО «Кемеровский государственный сельскохозяйственный институт, 650021 Российская Федерация. Кемерово, ул. Карла Маркса, 12, е- mail:pvm1947@bk.ru.

Австриевских Александр Николаевич, доктор технических наук, профрессор, генеральный директор НПО «Арт Лайфр», е-mail: pvm1947@bk.ru.

Позняковский Валерий Михайлович, Заслуженный деятель науки Российской фредерации, д. б. н, профрессор кафредры «Технологий питания» ФГБОУ ВО «Уральский государственный экономический университет», 620019, Российская Федерация, г. Екатеринбуре, ул. 8 марта, 62, e-mail:pvm1947@bk.ru. 